\title{
Protective Effects of 3-benzoyl-7-hydroxy Coumarin on Liver of Adult Rat Exposed to Aluminium Chloride
}

\author{
Ahmet Özkaya ${ }^{*}$ and Kenan Türkan \\ Department of Chemistry, Faculty of Science and Art, Adiyaman University, Adiyaman, Turkey \\ *Corresponding author: E-mail: aozkaya@adiyaman.edu.tr \\ Telephone: $+90-416-2233800$
}

Received: 09-17-2020

\begin{abstract}
In this study, the effects of 3-benzoyl-7-hydroxy coumarin molecule on mineral and antioxidant enzymes were investigated in rat liver exposed to oxidative stress with aluminium chloride $\left(\mathrm{AlCl}_{3}\right)$. Adult male Wistar albino rats were divided into four groups as Control, Coumarin, $\mathrm{AlCl}_{3}$, and Coumarin $+\mathrm{AlCl}_{3}$. Coumarin at the dose of $10 \mathrm{mg} / \mathrm{kg}$ and $\mathrm{AlCl}_{3}$ at the dose of $8.3 \mathrm{mg} / \mathrm{kg}$ were administered for 30 days every other day. In $\mathrm{AlCl}_{3}$ group, malondialdehyde (MDA), iron ( $\mathrm{Fe}$ ), aluminium $(\mathrm{Al})$ and copper $(\mathrm{Cu})$ levels increased compared to the control group, while glutathione (GSH) level, glutathione S-transferase (GST), and carboxylesterase (Ces) enzyme activity levels decreased. In Coumarin $+\mathrm{AlCl}_{3}$ group, MDA, $\mathrm{Fe}, \mathrm{Al}$ and $\mathrm{Cu}$ levels decreased with the effect of coumarin compared to $\mathrm{AlCl}_{3}$ group, while $\mathrm{GSH}$ level, and GST enzyme activity levels increased. According to our results, $\mathrm{AlCl}_{3}$ generates oxidative stress in rat livers, and we believe that 3-benzoyl-7-hydroxy coumarin has an ameliorative effect on antioxidant enzyme system, $\mathrm{Al}, \mathrm{Fe}$ and $\mathrm{Cu}$ levels.
\end{abstract}

Keywords: Aluminium; coumarin; rat; liver; carboxylesterase; mineral

\section{Introduction}

Aluminium (Al) is a metal commonly found in soil. People are exposed to Al throughout life in many ways such as through cooking utensils, drinking water, antacids, deodorants, food additives, spices, teas and dialysis processes. $\mathrm{Al}$ accumulates in many organs such as liver, brain, heart and lung. As a result of its toxic effects, $\mathrm{Al}$ causes many disorders such as anaemia, brain diseases, muscle weakness and lung problems. ${ }^{1,2}$ In particular, in Alzheimer's Disease, it has been suggested to play a role in the progression of the disease. ${ }^{3}$ Liver is one of the most important organs of metabolism, regulating detoxification and secretory functions. Studies have reported that $\mathrm{Al}$ accumulates in liver and causes harmful effects. ${ }^{4,5}$ Significant changes in haemato-biochemical parameters of rats and rabbits exposed to $\mathrm{Al}$ were detected. $\mathrm{Al}$ causes an increase in hepatic MDA levels and a decrease in antioxidant enzymes. ${ }^{6,7}$

Coumarins are defined as "2H-1-benzopyran-2-on". These chemicals are one of the important members of the natural class of polyphenolic compounds. ${ }^{8}$ In addition to being isolated from plants, coumarins were also synthesized synthetically. Coumarins have many biochemical effects such as anticancer, ${ }^{9}$ antiinflammatory, ${ }^{10}$ and antihyperlipidemic. ${ }^{11}$ In our study, 3-benzoyl-7-hydroxy cou- marin was used. Hydroxycoumarins are a phenolic compound. The free radical scavenger and metal chelator properties of these substances are known. ${ }^{12}$

There are many esterase enzymes such as acetylcholine esterase, buthylcholin esterase, carboxylesterase, cholesterol esterase, which differ in biological functions in our body. Increases in metabolites produced by these enzymes can lead to pathological conditions, such as Alzheimer's Disease, hypercholesterolemia, brain cancer, and Coronary Artery Disease; and therefore, researchers have focused on various esterase inhibitors. ${ }^{13}$ Among these enzymes, carboxylesterase is an important detoxification enzyme. Carboxylesterase (Ces, EC 3.1.1.1) is a member of the superfamily of esterase that catalyses the hydrolysis of esters, amides and thioesters. ${ }^{14}$ These enzymes are expressed mainly in the liver of mammals. ${ }^{15}$ Many drugs and xenobiotics have effects on the influence expression of Ces enzymes. ${ }^{16}$ Another important detoxification enzyme is Glutathione S-transferase (GST). The most important task of this enzyme is to scavenge reactive oxygen species (ROS). ${ }^{17}$ Reduced glutathione (GSH) is a non-enzymatic antioxidant molecule, and is essential for antioxidant functions. ${ }^{18}$ Macro and trace elements have many functions in human metabolism, such as cofactors and antiox- 
idants. Lack and excess of elements in metabolism cause serious damage. In some studies, it has been reported that the levels of other elements change as a result of $\mathrm{Al}$ exposure. ${ }^{19}$

There is information in the literature about the protective role of various coumarin derivatives (fraxin, esculetin, grandi vittin, agosyllin, aegolinol benzoate, osthol etc.) against oxidative stress ${ }^{8}$, but there is no information about the effect of the 3-benzoyl-7-hydroxy coumarin we used in our study against oxidative stress. Therefore, in the present study, the effects of 3-benzoyl-7-hydroxy coumarin on $\mathrm{Fe}, \mathrm{Al}, \mathrm{Cu}$, zinc $(\mathrm{Zn})$, magnesium $(\mathrm{Mg})$, manganese (Mn), CES, GST, GSH and MDA were investigated in the liver of rats exposed to $\mathrm{AlCl}_{3}$.

\section{Materials and Methods}

\section{1. Animals and Experimental Procedure}

All experimental protocols were approved by the Local Ethics Committee of Adiyaman University (Number of the permission: 2019/27). Rats used in the experiment were treated in accordance with national and international laws and policies regarding the care and use of experimental animals. Twenty-eight adult (aged 2.5 months) male Wistar albino rats (260 $\pm 10 \mathrm{~g}$ body weight) were obtained from the Department of Animal Experiments Local Ethics Committee of Adiyaman University (Adiyaman, Turkey). Rats were randomly divided into four groups as Control (C), 3-benzoyl-7-hydroxy coumarin (CM), $\mathrm{AlCl}_{3}(\mathrm{~A})$, and 3-benzoyl-7-hydroxy coumarin $+\mathrm{AlCl}_{3}(\mathrm{CM}+\mathrm{A}) \quad(\mathrm{n}=7$ each group). The $\mathrm{C}$ group rats received vehicle solutions with only distilled water. $\mathrm{AlCl}_{3}$ was dissolved in distilled water, and the animals were given $8.3 \mathrm{mg} / \mathrm{kg}$ intraperitoneally (IP). ${ }^{20}$ 3-benzoyl-7-hydroxy coumarin was administered to the animals in distilled water at a dose of $10 \mathrm{mg}$ / kg orogastrically. ${ }^{21}$ During the application, in order to prevent possible complex formation between aluminium and coumarin, $\mathrm{AlCl}_{3}$ and coumarin exposures were applied at different time intervals. The exposure of $\mathrm{AlCl}_{3}$ was made between 09:00 am and 10:00 am every other day for 30 days. Coumarin administration was performed between 04:00 pm and 05:00 pm every other day for 30 days. The rats were housed under a standard light/dark schedule (12-h light/12-h dark cycle) at constant temperature (21 \pm $\left.1^{\circ} \mathrm{C}\right)$ and humidity $(55 \pm 5 \%)$ with free access to pelleted food and fresh tap water. The rats were sacrificed at the end of day 30. For biochemical analyses, liver samples were stored at $-50^{\circ} \mathrm{C}$ until the assays were performed.

\section{2. Homogenization and Centrifugation of Liver Tissue}

Ice-cooled $0.1 \mathrm{M}$ K-phosphate buffer containing 0.15 $\mathrm{M} \mathrm{KCl}, 1 \mathrm{mM}$ EDTA and $1 \mathrm{mM}$ DTT in a $1: 4$ ratio of total tissue weight $(\mathrm{w} / \mathrm{v})$ was used to homogenize liver samples.
Homogenization was performed with a Heidolph RZ 2021 brand homogenizer. The homogenates were centrifuged at $15000 \mathrm{~g}$ for 30 minutes at 4 degrees Celsius using the Hettich ROTINA $420 \mathrm{R}$ centrifuge. The supernatant obtained after centrifugation was used for testing enzyme activity. The levels of MDA, reduced GSH, and activities of Ces and GST were determined spectrophotometrically at appropriate wavelengths using a microplate reader system (ThermoTM Varioskan Flash, Thermo Scientific).

\section{3. Measurement of Glutathione S-transferase Activities}

The GST activity was measured using a modified version of the method developed by Habig et al. (1974), and adapted to the microplate reader system. ${ }^{22}$ The mixture consisted of $100 \mathrm{mM} \mathrm{K}$-phosphate buffer ( $\mathrm{pH}$ 6.5), 1 $\mathrm{mM} \mathrm{GSH}$ (used as cofactor), $10 \mathrm{mM} \mathrm{CDNB}$ (used as a substrate) and supernatant. During the measurement, $10 \mathrm{mi}$ croliter supernatant, 100 microliters phosphate buffer + $100 \mu \mathrm{l} \mathrm{GSH}$ mixture and finally CDNB were pipetted into microplate wells, respectively. Absorbance changes expressing the decrease in $\mathrm{CDNB}$ amount depending on the reduced GSH consumed during the reaction were measured at $344 \mathrm{~nm}$ for $3 \mathrm{~min}$ at $25^{\circ} \mathrm{C}$, and the specific GST activity was calculated as nmol $\mathrm{min}^{-1} \mathrm{~g}$ protein ${ }^{-1}$.

\section{4. Measurement of Ces Activities}

The Ces activity was determined using the modified version of the procedure described by Santhoshkumar and Shivanandappa (1999) for the microplate reader. ${ }^{23}$ The reaction solution consisted of $5 \mu \mathrm{L}$ of supernatant and 0.1 $\mathrm{mM} 250 \mu \mathrm{L}$ pH 7.4 trizma buffer. The reaction mixture pipetted into microplate wells was incubated for $3 \mathrm{~min}$ at 25 ${ }^{\circ} \mathrm{C}$. The reaction was initiated by the addition of $5 \mu \mathrm{L}$ of the $0.5 \mathrm{mM}$ p-nitrophenol acetate (PNPA), into the reaction solution in wells. The p-nitrophenol released during the reaction due to the use of $\mathrm{p}$-nitrophenol acetate as a substrate by Ces was monitored at $405 \mathrm{~nm}$ for $2 \mathrm{~min}$ at $25^{\circ} \mathrm{C}$. The specific Ces activity was calculated as $\mathrm{nmol} \mathrm{min}^{-1} \mathrm{~g}$ protein $^{-1}$.

\section{5. Determination of Malondialdehyde and Reduced GSH Levels in Tissues}

The analysis of MDA, a secondary product of lipid peroxidation was carried out as described by Placer et al. (1966). ${ }^{24}$ The reaction mixture was freshly prepared by adding $500 \mu \mathrm{L}$ homogenate to $1.5 \mathrm{~mL}$ reaction solution by mixing equal volume of $15 \%$ trichloroacetic acid, $0.375 \%$ thiobarbituric acid, $0.25 \mathrm{~N} \mathrm{HCl}(1: 1: 1, \mathrm{w} / \mathrm{v})$. The reaction mixture was heated for $30 \mathrm{~min}$ at $100{ }^{\circ} \mathrm{C}$ in a water bath. After the mixture was cooled to room temperature, the centrifugation was performed at $15000 \mathrm{~g}$ for $15 \mathrm{~min}$. Subsequently, by transferring supernatant samples into mi- 
croplate wells, absorbance changes depending on MDA formed during the reaction were recorded at $532 \mathrm{~nm}$. MDA levels were expressed as ( $\mathrm{nmol} / \mathrm{g}$ wet weight tissue). The reduced GSH level was determined by measuring the absorbance value at $412 \mathrm{~nm}$ of a compound formed by the reaction of reduced GSH with 5.5-dithiobis 2-nitro-benzoic acid (DTNB). ${ }^{25}$ The level of reduced GSH was expressed as nmol mg ${ }^{-1}$ protein.

\section{6. Determination of Total Protein in Samples}

The total protein content in the supernatant samples was determined using the colourimetric method of Bradford 1976, and with Bovine Serum Albumin (BSA) as the standard. ${ }^{26}$ Results were expressed as milligram protein. All analyses were performed in triplicates. Total protein level was used to determine for GSH level and CES, GST enzyme activities in the liver.

\section{7. Liver Mineral Analyses}

Liver $\mathrm{Al}, \mathrm{Fe}, \mathrm{Cu}, \mathrm{Zn}, \mathrm{Mg}$, and $\mathrm{Mn}$ concentrations were measured using a NexION 350 inductively-coupled plasma mass spectrometer (ICP-MS, Perkin Elmer, MA, USA) at the Central Research Laboratory of Adiyaman University. The livers $(250 \mathrm{mg})$ were digested in an acid solution $\left(5 \mathrm{ml}\right.$ of nitric acid $\left(\mathrm{HNO}_{3}, 65 \%\right)$ using a microwave digestion system. ${ }^{27}$ The digestion solutions were diluted and analysed by using the ICP-MS. For quality control, duplicate samples were used to measure the precision of the analysis. Detection limits were calculated as three times the standard deviation for the reagent blanks. ${ }^{28}$ The results of the liver mineral concentrations are presented as ppm for $\mathrm{Al}, \mathrm{Fe}, \mathrm{Cu}, \mathrm{Zn}, \mathrm{Mg}$, and $\mathrm{Mn}$.

\section{8. Synthesis of 3-benzoyl-7-hydroxy Coumarin Molecule}

The synthesis of 3-benzoyl-7-hydroxy coumarin compound was carried out according to reference ${ }^{29}$ briefly as follows: 2.4-dihydroxybenzaldehyde (2.762 g), ethyl benzoyl acetate ( $3.844 \mathrm{~g}$ ), piperidine (three drops) and acetone $(50 \mathrm{~mL})$ were added into a three-necked reaction flask and then, it was refluxed for 2 hours on a magnetic stirrer. At the end of the process, the reaction mixture was transferred into excess methanol to precipitate the 3-benzoyl-7-hydroxy coumarin compound (Figure 1). Finally, it was recrystallized in ethanol and dried under vacuum.<smiles>O=C(c1ccccc1)c1cc2ccc(O)cc2oc1=O</smiles>

Figure 1: Schematic representation of 3-benzoyl-7-hydroxy coumarin

\section{9. Statistical Analyses}

Data were expressed as mean \pm SEM (standard error of mean). Statistical comparison of biochemical parameters was done using One-Way Analysis of Variance followed by the Tukey-HSD test. $\mathrm{P}<0.05$ was considered to be statistically significant.

\section{Results}

Liver mineral levels are presented in Table 1. Fe and $\mathrm{Cu}$ levels of group $\mathrm{A}$ increased compared to all other groups $(\mathrm{p}<0.05)$. There was no statistical difference between the $\mathrm{Zn}$ levels of all groups $(\mathrm{p}>0.05)$. While the $\mathrm{Al}$ level of group A increased compared to all other groups ( $\mathrm{p}<0.001, \mathrm{p}<0.05)$, Al level of $\mathrm{CM}+\mathrm{A}$ group decreased compared to A group ( $\mathrm{p}$ 0.05). Mn levels of A and CM+A groups decreased compared to $\mathrm{C}$ and $\mathrm{CM}$ groups.

Table 1: Liver mineral levels (ppm)

\begin{tabular}{lrccc}
\hline Minerals & \multicolumn{1}{c}{$\mathbf{C}$} & $\mathbf{C M}$ & $\mathbf{A}$ & $\mathbf{C M}+\mathbf{A}$ \\
\hline $\mathrm{Fe}$ & $103.20 \pm 3.49$ & $100.55 \pm 3.00^{\mathrm{x}}$ & $116.84 \pm 2.38^{\mathrm{a}}$ & $102.25 \pm 2.2^{\mathrm{x}}$ \\
$\mathrm{Zn}$ & $25.79 \pm 1.66$ & $25.95 \pm 0.66$ & $24.43 \pm 1.26$ & $29.16 \pm 1.22$ \\
$\mathrm{Mg}$ & $238.06 \pm 6.09$ & $230.34 \pm 5.11$ & $232.74 \pm 9.28$ & $240.56 \pm 1.93$ \\
$\mathrm{Al}$ & $29.98 \pm 3.64$ & $28.75 \pm 3.08^{\mathrm{z}}$ & $94.14 \pm 5.44^{\mathrm{c}}$ & $69.07 \pm 6.33^{\mathrm{cx}}$ \\
$\mathrm{Mn}$ & $2.90 \pm 0.07$ & $2.94 \pm 0.06^{\mathrm{x}}$ & $2.55 \pm 0.04^{\mathrm{a}}$ & $2.65 \pm 0.09^{\mathrm{a}}$ \\
$\mathrm{Cu}$ & $5.37 \pm 0.76$ & $4.69 \pm 0.23^{\mathrm{x}}$ & $7.32 \pm 0.53^{\mathrm{a}}$ & $5.29 \pm 0.40^{\mathrm{x}}$ \\
\hline
\end{tabular}

Comparison with group C. a: $\mathrm{p}<0.05$, b: $\mathrm{p}<0.01, \mathrm{c}: \mathrm{p}<0.001$

Comparison with group A. $\mathrm{x}: \mathrm{p}<0.05, \mathrm{y}: \mathrm{p}<0.01, \mathrm{z}: \mathrm{p}<0.001$

Liver MDA, GSH and enzyme activity levels are shown in Table 2. Group A's MDA level was found to be increased compared to other groups ( $\mathrm{p}<0.001 ; \mathrm{p}<0.05$ ). GSH level of group A decreased compared to other groups ( $\mathrm{p}<0.05 ; \mathrm{p}<0.001)$. Ces enzyme activity levels of $\mathrm{A}$ and $\mathrm{CM}+\mathrm{A}$ groups decreased compared to $\mathrm{C}$ and $\mathrm{CM}$ groups $(\mathrm{p}<0.05)$. GST enzyme activity level of A group decreased compared to other groups $(\mathrm{p}<0.05)$.

Table 2: MDA, GSH and enzyme activity levels of the liver. GST and Ces activities are expressed as $\mathrm{nmol} / \mathrm{min} / \mathrm{mg}$ protein \pm mean standard error. GSH and MDA levels are expressed as nmol GSH/mg protein \pm mean standard error, and $\mathrm{nmol} \mathrm{MDA} / \mathrm{g}$ wet weight tissue \pm mean standard error, respectively.

\begin{tabular}{lrrrr}
\hline Parameters & C & CM & A & CM+A \\
\hline MDA & $45.02 \pm 2.54$ & $48.05 \pm 3.41^{\mathrm{z}}$ & $78.75 \pm 5.85^{\mathrm{c}}$ & $58.56 \pm 3.65^{\mathrm{ax}}$ \\
GSH & $88.45 \pm 3.02$ & $96.41 \pm 4.23^{\mathrm{z}}$ & $73.75 \pm 4.05^{\mathrm{a}}$ & $86.32 \pm 5.45^{\mathrm{x}}$ \\
Ces & $1.78 \pm 0.06$ & $1.81 \pm 0.05^{\mathrm{x}}$ & $1.47 \pm 0.02^{\mathrm{a}}$ & $1.48 \pm 0.09^{\mathrm{a}}$ \\
GST & $31.41 \pm 0.76$ & $33.80 \pm 1.67^{\mathrm{x}}$ & $24.34 \pm 1.04^{\mathrm{a}}$ & $32.20 \pm 1.90^{\mathrm{x}}$ \\
\hline
\end{tabular}

Comparison with group C. a: $\mathrm{p}<0.05, \mathrm{~b}: \mathrm{p}<0.01, \mathrm{c}$ : $\mathrm{p}<0.001$

Comparison with group A. $x: p<0.05, y: p<0.01, z: p<0.001$ 


\section{Discussion}

$\mathrm{Al}$ is a metal commonly found in air, soil and water. This metal is widely used in industry, agriculture, transportation and daily lives of people. Al, absorbed by the gastrointestinal tract, accumulates in the liver and other organs. In many studies, $\mathrm{Al}$ has been reported to cause hepatotoxicity, nephrotoxicity and cardiotoxicity. ${ }^{30,31}$

In the present study, we observed that $\mathrm{Al}, \mathrm{Fe}$ and $\mathrm{Cu}$ concentrations increased significantly in the liver of rats that were given $\mathrm{AlCl}_{3}$ intraperitoneally. In many experimental studies, it has been reported that the concentration of $\mathrm{Al}$ increases in rat liver exposed to $\mathrm{Al} .{ }^{32,33} \mathrm{Al}$ is a non-redox metal, and many studies have reported that $\mathrm{Al}$ affects concentrations of other metal ions. ${ }^{34,35}$ Yang et al. reported that the $\mathrm{Al}, \mathrm{Fe}, \mathrm{Cu}$ concentrations were increased in rat liver overloaded with $\mathrm{Al} .{ }^{19}$ In addition, it has been reported that Fe levels increase in rat liver exposed to $\mathrm{Al}^{36} \mathrm{Al}$ is known to be linked to transfer protein carrying $\mathrm{Fe}^{3+}$, thereby reducing the binding of $\mathrm{Fe}^{2+}$. The increase in free intracellular $\mathrm{Fe}^{2+}$ causes peroxidation of membrane lipids, thereby causing membrane damage. ${ }^{37}$ Chronic $\mathrm{Cu}^{2+}$ and $\mathrm{Fe}^{3+}$ overload causes accumulation of $\mathrm{Cu}^{2+}$ and $\mathrm{Fe}^{3+}$ in the liver and kidney, which causes $\mathrm{Fe}^{2+}$ overload. $\mathrm{Al}$ has been reported to increase Fe-induced oxidative stress injuries. ${ }^{38-40}$

In this study, liver Mn concentration of the $\mathrm{A}$ and combination groups decreased compared to the $\mathrm{C}$ group. In some studies, it has been reported that the Mn concentration decreases in rat liver exposed to $\mathrm{Al}^{41,42}$ In our study, we observed that the $\mathrm{Zn}$ and $\mathrm{Mg}$ concentration levels of group A decreased relatively compared to group C. Trace elements have important physiological functions in metabolism, and their abnormal usability causes serious negative effects. Trace elements, such as $\mathrm{Cu}, \mathrm{Zn}, \mathrm{Fe}, \mathrm{Mn}$, and $\mathrm{Mg}$ are essential co-factors for antioxidant enzymes. These enzymes are very important in preventing the oxidation of nucleic acids, lipids or proteins. ${ }^{43}$

In our study, the level of MDA increased in rat liver treated with $\mathrm{AlCl}_{3}$. Also, GSH levels and GST and Ces enzyme activity levels decreased in antioxidant defence system. Based on these results, we believe that increased oxidative stress with $\mathrm{AlCl}_{3}$ and reduction of enzymes involved in antioxidant defence could be caused by peroxidation damages. The glutamyl-cysteine-synthetase enzyme carries out the synthesis of the GSH molecule in the liver. In addition, it was found that enzymes, such as glucose-6-phosphate dehydrogenase and NADP-isocitrate dehydrogenase control the synthesis of the GSH molecule in the liver. In many studies, the inhibition effect of $\mathrm{AlCl}_{3}$ on enzymes controlling GSH biosynthesis has been reported. $\mathrm{AlCl}_{3}$ has pro-oxidant activity, and causes changes in the activity of antioxidant enzymes. In similar studies, while $\mathrm{AlCl}_{3}$ increased the level of MDA in rat liver, it decreased GSH level and the activity of Glutathione peroxidase (GSH-Px), superoxide dismutase (SOD) and catalase. ${ }^{4-46}$ In another study, it was reported that activities of catalase, GPx, SOD, and GST enzyme decreased in rat liver tissues with the toxic effects of $\mathrm{Al}^{47}$

In the present study, it was observed that the $\mathrm{Al}, \mathrm{Fe}$ and $\mathrm{Cu}$ levels increased in the liver of the rats exposed to oxidative stress with $\mathrm{AlCl}_{3}$, and the 3-benzoyl-7-hydroxy coumarin substance decreased the levels of these metals. In addition, it was determined that the level of MDA, which is the high lipid peroxidation product of $\mathrm{AlCl}_{3}$, was reduced by 3-benzoyl-7-hydroxy coumarin. It was observed that 3-benzoyl-7-hydroxy coumarin substance improved the GSH level and GST enzyme activity, which are effective in the antioxidant system. In this study, Ces enzyme activity decreased due to the toxic effect of $\mathrm{AlCl}_{3}$. Also, in the combination group, the activity of Ces enzyme decreased with the effect of 3-benzoyl-7-hydroxy coumarin.

The results of the present study show that 3-benzoyl-7-hydroxy coumarin exerted antioxidant properties against the pro-oxidant effects of $\mathrm{AlCl}_{3}$. We found that 3-benzoyl-7-hydroxy coumarin improves both $\mathrm{Al}, \mathrm{Fe}$ and $\mathrm{Cu}$ concentrations in the liver, and positively affects the antioxidant system. The antioxidant activity of coumarin is due to its ability to scavenge free radicals and chelate metal ions. The antioxidant capacity of many coumarin substances has been reported to be due to its molecular structure. ${ }^{48}$ The number and location of hydroxy, acetoxy and methoxy groups in the structure of coumarin affect the antioxidant capacity. These functional groups are very important for detoxification functions of coumarins. ${ }^{48} \mathrm{In}$ a similar study, the hepatoprotective effect of four different coumarins (coumarin (1,2- benzopyran), esculetin (6,7-dihydroxycoumarin), scoparone (6,7-dimethoxycoumarin), and 4-methylumbelliferone (7-hyroxy-4- methyl) were investigated against hepatic damage caused by $\mathrm{CCl}_{4}$ in rat liver, and it was reported that two coumarins (esculetin and scoparone) had hepatoprotective effects. It has been explained that antioxidant properties of coumarins are attributed to their chemical structure. ${ }^{49}$ In another study, the ameliorative effect of coumarin (1,2-benzopyron) was investigated in rats with ferric nitrilotriacetate (Fe-NTA)-induced renal oxidative stress. Fe-NTA increases the level of MDA with the effect of oxidative stress while decreasing the GSH level and GST enzyme activity. However, the ameliorative effect of the coumarin (1,2-benzopyrone) molecule has also been reported. ${ }^{48}$ Many studies have shown that coumarin has an antioxidative effect against various oxidative stress agents. ${ }^{50-52}$ Atmaca et al. (2011) suggested that coumarin and its derivatives showed antioxidative effects against rat liver damage induced by carbon tetrachloride by testing various antioxidant biomarkers. ${ }^{49}$ Various studies have shown that coumarin derivatives, such as fraxin, esculetin, grandivittin, agacyllin, aegolinol benzoate and osthol have free radical scavenging effects. ${ }^{8}$

In our study, we revealed the relationship between the toxic effect of $\mathrm{Al}$ on the liver and the detoxification enzymes such as Ces and GST. Al reduced GST and Ces en- 
zyme activities in rat liver. We could not find studies related to Ces enzyme activity to compare our results; however, there are reports indicating that $\mathrm{Al}$ decrease GST enzyme activity. In our previous study, we had found that Ces and GST enzyme activities decreased in liver of rats given lead acetate. ${ }^{53}$ In this study, although we saw the ameliorative effect of 3-benzoyl-7-hydroxy coumarin in GST enzyme activity, we also found that this had no ameliorative effect on Ces enzyme activity in the combination group. It may be considered that the ineffectiveness of coumarin on Ces activity depends on the dose applied. Perhaps Ces activity would have been affected if different doses of coumarin were tried. We believe that more in vitro and in vivo studies are needed regarding the effect of coumarin on Ces activity. In the study conducted by Khan et al., it was reported that coumarin applied in increasing doses against the oxidative stress induced by Fe-NTA has an ameliorative effect on GST enzyme activity at high dose. ${ }^{48}$

In advanced pharmacological studies, we believe that this study is important for the effects of coumarin-derived substances on Ces enzyme activities.

\section{Conclusion}

In conclusion, we observed that $\mathrm{AlCl}_{3}$ induces oxidative stress in rat liver. We have determined ameliorative effects of 3-benzoyl-7-hydroxy coumarin on deleterious effects of aluminium on the antioxidant enzymes, $\mathrm{Fe}, \mathrm{Cu}$ and $\mathrm{Al}$ levels. However, we observed that the 3-benzoyl-7-hydroxy coumarin did not ameliorate the effect of Ces enzyme activity. In future studies, we believe that this study is important for investigating the effects of toxic substances and coumarin derivatives on Ces enzyme activity. As a result, we believe that 3-benzoyl-7-hydroxy coumarin may have an ameliorative effect against oxidative stress induced by $\mathrm{Al}$.

\section{Funding Information}

This study was supported by Adiyaman University Scientific Research Projects Unit (ADYUBAP, Project no. FEFYL/2020-0001).

\section{Conflict of Interest}

The authors declare that they have no conflict of interest.

\section{References}

1. V. Kumar, K.D. Gill, Arch Toxicol. 2009, 83(11), 965978. DOI:10.1007/s00204-009-0455-6

2. L. A. Beyer, G. Greenberg, B. D. Beck, Hum Ecol Risk Assess.2014, 20(1),111-136.
DOI:10.1080/10807039.2013.770350

3. H. Luo, G. Liu, R. Zhang, Y. Bai, S. Fu, Y. Hou, J Hazard Mater.2014, 270,153-159.

DOI:10.1016/j.jhazmat.2014.01.050

4. M. A. Gonzalez, M. L. Alvarez, G. B. Pisani, C. A. Bernal, M. G. Roma, M. C. Carrillo, Biol Trace Elem Res. 2007, 116, 329-348. DOI:10.1007/BF02698017

5. M. A. Gonzalez, C. A. Bernal, S. Mahieu, M. C. Carrillo, Biol Trace Elem Res. 2009, 127 (2),164-176.

DOI:10.1007/s12011-008-8234-4

6. M. I. Yousef, Toxicology. 2004, 199 (1), 47-57. DOI:10.1016/j.tox.2004.02.014

7. A. S. Newairy, A. F. Salama, H. M. Hussien, M. I. Yousef, Food Chem Toxicol. 2009, 47(6),1093-1098.

DOI:10.1016/j.fct.2009.01.032

8. K. N. Venugopala, V. Rashmi, B. Odhav, Biomed Res Int. 2013, 2013:963248. DOI:10.1155/2013/963248

9. K. V. Sashidhara, A. Kumar, M. Kumar, J. Sarkar, S. Sinha, Bioorg Med Chem Lett. 2010, 20(24), 7205-11. DOI:10.1016/j.bmcl.2010.10.116

10. C. A. Kontogiorgis, D. J. Hadjipavlou-Litina, J Med Chem. 2005, 48(20), 6400-6408.

DOI:10.1021/jm0580149

11. K. V. Sashidhara, A. Kumar, M. Kumar, A. Srivastava, A. Puri, Bioorg Med Chem Lett. 2010, 20, 6504-6507.

DOI:10.1016/j.bmcl.2010.09.055

12. E. J. Lien, S. Ren, H. H. Bui, R. Wang, Free Radic Biol Med. 1999, 26(3-4), 285-94.

DOI:10.1016/S0891-5849(98)00190-7

13. M. Alipour, M. Khoobi, A. Foroumadi, H. Nadri, A. Moradi, A. Sakhteman, M. Ghandi, A. Shafiee, Bioorg Med Chem, 2012, 20, 7214-7222.

DOI:10.1016/j.bmc.2012.08.052

14. M. K Ross, A. Borazjani, C.C. Edwards, P. M. Potter, Biochem Pharmacol. 2006, 71(5), 657-69.

DOI:10.1016/j.bcp.2005.11.020

15. E. W Morgan, B. Yan, D. Greenway, A, Parkinson, Arch Biochem and Biophy. 1994, 315(2), 513-526.

DOI:10.1006/abbi.1994.1532

16. R. S. Holmes, M. W. Wright, S. J. F. Laulederkind, L. A. Cox, M. Hosokawa, T. Imai, S. Ishibashi, R. Lehner, M. Miyazaki, E. J. Perkins, P. M. Potter, M. R. Redinbo, J. Robert, T. Satoh, T. Yamashita, B. Yan, T. Yokoi, R. Zechner, L. J. Maltais, Mamm Genome. 2010, 21(9-10), 427-441. DOI:10.1007/s00335-010-9284-4

17. S. Amjad, S. Umesalma, J Mol Biomark Diagn. 2015, 6(1), 1-7.

18. L. DeLeve, N. Kaplowitz, Pharmacol Ther. 1991, 52(3), 287-305. DOI:10.1016/0163-7258(91)90029-L

19. Y. Yang, H. Wang, Y. Guo, W. Lei, J. Wang, X. Hu, J. Yang, Q. He, Biol Trace Elem Res. 2016, 173, 126-131. DOI:10.1007/s12011-016-0627-1

20. A. Ozkaya, S. Celik, A. Yuce, Z. Sahin, O. Yilmaz, Kafkas Univ Vet Fak Derg. 2010, 16 (2): 263-268.

21. N. Khan, S. Sharma, S. Sultana, Redox Rep. 2004, 9(1), 19-28. DOI: $10.1179 / 135100004225003860$ 
22. W. H. Habig, M. J. Pabst, W. B. Jakoby, J Biol Chem. 1974, 249(22), 7130-7139.

23. P. Santhoshkumar, T. Shivanandappa, Chem Biol Interact. 1999, 119-120, 277-282. DOI:10.1016/S0009-2797(99)00037-X

24. Z. A. Placer, L. L. Cushman, B. C. Johnson, Anal Biochem. 1966, 16(2), 359-364.

DOI:10.1016/0003-2697(66)90167-9

25. M. S. Moron, J. W. Depierre, B. Mannervik, Biochim Biophys Acta. 1979, 582(1), 67-78.

DOI:10.1016/0304-4165(79)90289-7

26. M. M. Bradford, Anal Biochem. 1976, 72, 248-254.

DOI:10.1016/0003-2697(76)90527-3

27. S. Rattanachongkiat, G. E. Millward, M. E. Foulkes, $J$ Environ Monit. 2004, 6(4):254-261. DOI:10.1039/B312956J

28. I. De Blas Bravo, R. S. Castro, N. L. Riquelme, C. T. Diaz, D.A., J Trace Elem Med Biol. 2007, 21(1):14-17. DOI:10.1016/j.jtemb.2007.09.017

29. A. Kurt, A. F. Ayhan, M. Koca, Sakarya Univ J Sci. 2018, 22(3),880-887.

30. G. Crisponi, D. Fanni, C. Gerosa, S. Nemolato, V.M. Nurchi, M. Crespo-Alonso, J. I. Lachowicz, G. Faa, Biomol Concepts. 2013, 4(1):77-87.

DOI:10.1515/bmc-2012-0045

31. F. Geyikoglu, H. Türkez, T. O. Bakir, M. Cicek, Toxicol Ind Health. 2013, 29(9), 780-791.

DOI:10.1177/0748233712440140

32. N. Kaneko, H. Yasui, J. Takada, K. Suzuki, H. Sakurai, $J$ Inorg Biochem. 2004, 98(12), 2022-2031.

DOI:10.1016/j.jinorgbio.2004.09.008

33. M. G. Abubakar, A. Taylor, G. A. Ferns, Int J Exp Pathol. 2003, 84(1), 49-54.

DOI:10.1046/j.1365-2613.2003.00244.x

34. A. Mohammadiras, M. Abdollahi, Int J Pharmacol. 2011, 7(1), 12-21.

35. M. L. Turski, D. J. Thiele, J Biol Chem. 2009, 284(2), 717-721. DOI:10.1074/jbc.R800055200

36. R. J. Ward, Y. Zhang, R. R. Crichton, J Inorg Biochem. 2001, 87(1-2), 9-14.

DOI:10.1016/S0162-0134(01)00308-7

37. B. Nehru, P. Anand, J Trace Elem Med Biol. 2005,19(23), 203-208. DOI:10.1016/j.jtemb.2005.09.004

38. H. Malhi, B. Joseph, M. L. Schilsky, S. Gupta, Regen Med. 2008, 3(2), 165-173.

DOI:10.2217/17460751.3.2.165

39. K. Bishu, R. Agarwal, Clin J Am Soc Nephrol. 2006, 1, 19-23.

40. A. Becaria, A. Campbell, S. C. Bondy, Toxicol Ind Health. 2002, 18(7), 309-20.

DOI:10.1191/0748233702th157oa

41. J. L. Esparza, M. Gomez, J. L. Domingo, Biol Trace Elem Res. 2019,188(1), 60-67.

DOI:10.1007/s12011-018-1372-4

42. A. Ozkaya, H. Ciftci, A. Dayangac, B.S. Cevrimli, A. Olcucu, S. Celik, Turk J Biochem. 2013, 38(3):345-349.
DOI:10.5505/tjb.2013.29291

43. C. Meplan, J Trace Elem Med Biol. 2011, 25(1), 11-16. DOI:10.1016/j.jtemb.2010.10.002

44. S. Shrivastava, J Trace Elem Med Biol. 2012, 26(2-3), 210-214. DOI:10.1016/j.jtemb.2012.04.014

45. M. E. Mahmoud, S. S. Elsoadaa, J Nat Sci Res. 2013, 3(1),102-112.

46. I. Bouasla, A. Bouasla, A. Boumendjel, M. Messarah, C. Abdennour, M. S. Boulakoud, A. E. Feki, Biol Trace Elem Res. 2014, 162(1-3),252-261.

DOI:10.1007/s12011-014-0114-5

47. N. H. Nour-Eldein, E. A. Hassanin, W. M. El-Sayed, Biol Trace Elem Res. 2018, 183(1):128-137.

DOI:10.1007/s12011-017-1126-8

48. N. Khan, S. Sharma, S. Sultana, Cancer Lett. 2004, 210(1), 17-26. DOI:10.1016/j.canlet.2004.01.011

49. M. Atmaca, H. M. Bilgin, B. D. Obay, H. Diken, M. Kelle, E. Kale, J Physiol Biochem. 2011, 67(4),569-76. DOI:10.1007/s13105-011-0103-5

50. H. C. Lin, S. H. Tsai, C. S. Chen, Y. C. Chang, C. M. Lee, Z. Y. Lai, C. M. Lin, Biochem Pharmacol, 2008, 75(6), 1416-1425. DOI:10.1016/j.bcp.2007.11.023

51. C. R. Wu, M. Y. Huang, Y. T. Lin, H. Y. J u, H. Ching, Food Chem, 2007, 104(4), 1464-1471.

DOI:10.1016/j.foodchem.2007.02.023

52. A. Tseng, Proc A. Assoc Cancer Res 1991, 32, 2257.

53. A. Ozkaya, Z. Sahin, M. Kuzu, Y.S. Saglam, M. Ozkaraca, M. Uckun, E. Yologlu, V. Comakli, R. Demirdag, S. Yologlu, Arch Physiol Biochem. 2018, 124(1), 80-87. DOI:10.1080/13813455.2017.1364772 


\section{Povzetek}

V tej raziskavi so so bili proučeni učinki molekule 3-benzoil-7-hidroksi kumarina na minerale in antioksidativne encime $\mathrm{v}$ jetrih podgan, izpostavljenih oksidativnemu stresu $\mathrm{z}$ aluminijevim kloridom $\left(\mathrm{AlCl}_{3}\right)$. Odrasli samci podgan Wistar albino so bili razdeljeni v štiri skupine, poimenovane kontrola, kumarin, $\mathrm{AlCl}_{3}$ in kumarin $+\mathrm{AlCl}_{3}$. Kumarin v odmerku $10 \mathrm{mg} / \mathrm{kg}$ in $\mathrm{AlCl}_{3} \mathrm{v}$ odmerku $8,3 \mathrm{mg} / \mathrm{kg}$ sta bila aplicirana $30 \mathrm{dni}$ vsak drugi dan. $\mathrm{V}$ skupini $\mathrm{AlCl}_{3}$ so se v primerjavi s kontrolno skupino zvišale koncentracije malondialdehida (MDA), železa (Fe), aluminija (Al) in bakra (Cu), medtem ko so se ravni glutationa (GSH) in encimske aktivnosti glutation S-transferaze (GST) in karboksilesteraze (Ces) zmanjšala. $\mathrm{V}$ skupini kumarin $+\mathrm{AlCl}_{3}$ so se ravni $\mathrm{MDA}, \mathrm{Fe}, \mathrm{Al}$ in $\mathrm{Cu} \mathrm{z}$ delovanjem kumarina zmanjšale v primerjavi s skupino $\mathrm{Al}-$ $\mathrm{Cl}_{3}$, medtem ko so se ravni GSH in aktivnost encima GST povečale. Glede na naše rezultate, $\mathrm{AlCl}_{3}$ povzroča oksidativni stres $\mathrm{v}$ jetrih podgan in verjamemo, da ima 3-benzoil-7-hidroksi kumarin blažilni učinek na antioksidativni encimski sistem in ravni $\mathrm{Al}, \mathrm{Fe}$ ter $\mathrm{Cu}$. 